\title{
TCMB, FED ve ECB Para Politikalarının Türkiye Ekonomisi Üzerindeki Etkileri: 1994-2014 Dönemi Analizi ${ }^{1}$
}

Elif ERER, Department of Economics, Institute of Social Sciences, Ege University, Turkey; e-mail: elif_erer_@hotmail.com

Deniz ERER, Department of Economics, Institute of Social Sciences, Ege University, Turkey; e-mail: denizerer@hotmail.com

Mustafa ÇAYIR, Department of Economics, Institute of Social Sciences, Ege University, Turkey; e-mail: mustafacayir89@gmail.com

Nasuh Ŏguzhan ALTAY, Department of Economics, Faculty of Economics and Administrative Sciences, Ege University, Turkey; e-mail: oguzhan.altay@ege.edu.tr

\section{The Effects of Monetary Policies by CBRT, FED and ECB on Turkish Economy: An Analysis for 1994-2014 Period $^{2}$}

\begin{abstract}
It is of extremely importance for policymakers to know how much time and what direction policy instruments affect macroeconomic variables in the selection of monetary policy instruments and in determination of how to implement in terms of the fluctuations in economic process. In this paper, the effects of monetary policies by CBRT, FED and ECB on macro economic variables in Turkey compared with each other considering high and low inflation regime by using TVAR method from the point of view of exchange rate channel, which is one of the monetary transmission mechanism between 1994:01 and 2014:10. Short-term (interbank) interest rate used as monetary policy instrument. The industrial production index has used to represent GDP as the measure of economic activity. Price level and exchange rate variables have measured by consumer price index and real effective exchange rate, respectively. Besides, crude oil has been taken into account as explatory variable.The results show that CBRT short-term interest rate affects both industrial production index and real exchange rate ppositively, but they also Show that FED affects only the real exchange rate positively in high inflation period. The response of real exchange rate is positive to CBRT short-term interest rate. However, this response is firstly positive then negative to
\end{abstract}

I Bu makale Sosyoekonomi Derneği ile Hacettepe Üniversitesi Piyasa Ekonomisini ve Girişsimciliği Geliştirme Merkezi tarafindan Almanya'nın Münih şehrinde, 29-30 Ekim 2015 tarihlerinde düzenlenen "Birinci Uluslararası Sosyoekonomi Derneği Yillık Buluşması"nda sunulan çalışmanın gözden geçirilmişs ve genişletilmiş halidir.

2 This article is the revised and extended version of the paper presented in "First International Annual Meeting of Sosyoekonomi Society" which was held by Sosyoekonomi Society and CMEE - Center for Market Economics and Entrepreneurship of Hacettepe University, in Munich/Germany, on October 29-30, 2015. 
FED and it is negative to ECB monetary policy. The monetary policies of CBRT, FED and ECB have also first positive then negatif effects on industrial production index, but they differentiate from each other in terms of the effect times of them. In conlusion, short-term interest policy the one of the FED monetary polices shown to be vital in the sense of Turkey once again.

Keywords

JEL Classification Codes :
CBRT, FED and ECB Monetary Policies, TVAR, Exchange Rate Channel.
C32, E00, E58.

\section{$\ddot{O} z$}

Ekonomik dalgalanmalar döneminde politika yapıcıların para politikası araçlarının seçimi ve bu araçların nasıl uygulanacağının belirlenmesi açısından politika araçlarının makroekonomik değişkenleri ne kadar süre ve hangi yönde etkilediklerini bilmeleri son derece önemlidir. Bu çalışmada, parasal aktarım mekanizması kanallarından döviz kuru kanalı açısından TCMB, FED ve ECB para politikalarının Türkiye'deki makro ekonomik değişkenler üzerindeki etkileri 1994:01-2014:10 dönemi için yüksek ve düşük enflasyon rejimi dikkate alınarak TVAR yöntemiyle karşılaştırılmaktadır. Para politikası aracı olarak kısa dönem faiz oranı (interbank) değişkeni kullanılmıştır. Gayri safi yurtiçi hasılayı (GSYİH) temsilen ekonomik faaliyeti ölçen sanayi üretim endeksi kullanılmıştır. Fiyat düzeyi ve döviz kuru, tüketici fiyat endeksi ve reel efektif döviz kuru ile ölçülmüştür. Çalışmada petrol fiyatları ise açıklayıcı değişken olarak modele dâhil edilmiştir. Yapılan analizden elde edilen sonuçlar, yüksek enflasyon döneminde TCMB kısa dönem faiz oranı politikasının hem sanayi üretim endeksi, hem de reel döviz kurunu, FED uygulamalarının da sadece reel döviz kurunu pozitif olarak etkilediğini göstermektedir. Düşük enflasyon döneminde, reel döviz kuru TCMB kısa dönem faiz oranına pozitif, FED karşısında önce pozitif daha sonra negatif ve son olarak ECB para politikasına negatif bir tepki vermektedir. TCMB, FED ve ECB para politikalarının sanayi üretim endeksi üzerinde önce pozitif daha sonra negatif etkiye sahiptir. Ancak bu etki süreleri bakımından farklılaşmaktadır. Sonuç olarak, FED tarafından uygulanan kısa dönem faiz politikasının Türkiye için son derece önemli olduğu ifade edilebilir.

\section{Anahtar Sözcükler $\quad$ : $\quad$ TCMB, FED ve ECB Para Politikaları, TVAR, Döviz Kuru Kanalı.}

\section{Giriş}

Para politikaların başarısı, para otoriterlerinin uyguladıkları politikaların ekonomi üzerindeki etkileri ve zamanlamasının doğru bir şekilde değerlendirmeleri yanında, para politikasının ekonomiyi etkileyen mekanizmalarının anlaşılmasına bağlıdır (Mishkin, 1995: 4). Bu bağlamda para politikalarının etki analizinde parasal aktarım mekanizmaları (PAM) önem kazanmaktadır. PAM, merkez bankasının uyguladığı para politikası kararlarının genelde ekonomi, özelde fiyat mekanizması üzerindeki etkilerini ve bu etkilerin ne kadar süreceğini açıklamaktadır. Buradaki etkileşim, para politikası değişkenlerinin, para arzı ve faiz oranı üzerindeki etkisinden yola çıkarak, makro anlamda gelir ve fiyatlar genel düzeyinin belirlenmesine yönelik etkiyi dikkate alan bir yaklaşımdır. Para politikası bu ilişkiler ağının çıkış noktasını oluşturmaktadır. Reel sektör ve parasal sektör arasındaki köprünün nasıl kurulduğu parasal aktarım mekanizmaları ile 
açıklanabilmektedir (Atış, 2014: 115). Parasal aktarım mekanizması farklı kanallar üzerinden gerçekleşirken, bu kanallar birbirinin alternatifleri değildir. Ancak, ekonomik konjonktür bazı kanalları süreç içerisinde öne çıkarabilmektedir. Buna bağlı olarak da etki düzeyleri ülkelere ve ekonomik süreçlere göre farklılık gösterebilir. Sözü edilen aktarım kanalları, faiz oranları, döviz kuru, varlık fiyatları ve beklentiler üzerinden gerçekleşmekte ve dört ana başlıkta sınıflandırılabilmektedir (bkz. Halaç, 2015: 103-111).

Yukarıda kısaca açıklanan parasal aktarım mekanizması kanallarından döviz kuru kanalı hem toplam talebi, hem de toplam arzı etkilemektedir (TCMB, 2013: 7). Örneğin, genişleyici bir para politikası faiz oranlarında düşüşe neden olurken, ulusal para mevduatları, yabancı para cinsinden mevduatlara göre daha az çekici hale gelir ve yurtiçi mevduatların değeri düşer. Süreç, yurtiçi malların fiyatlarının ucuzlaması ile net ihracat ve toplam harcamaların artmasina neden olur (Mishkin, 2001: 7-8). Bu ve benzeri nedenlerle uluslararası ticaretin artması, ülkelerin esnek döviz kuru rejimlerine yönelmesi ve küreselleşme ile birlikte döviz kuru kanalı, ihracatı, çıktı açığı seviyesi ve enflasyonu etkileyerek parasal aktarım mekanizmasının işleyişinde önemli bir yer tutmaktadır (TCMB, 2013: 7).

Politika faiz oranında kısa dönemde meydana gelen dalgalanmalar merkez bankalarının uyguladıkları politika duruşlarındaki kaymaları yansıtmakta ve politikada ortaya çıkan hareketler geçmiş ekonomik koşullardan etkilenmektedir (Bernanke \& Blinder, 1992, s.917). Öte yandan, Dotsey ve Reid (1992), Leeper (1993), Shapiro (1994), Hoover ve Perez (1994), Sims ve Zha (1995), Bernanke, Gertler ve Watson (1997) para politikasının ekonomi üzerindeki etkilerini belirlemek için, politika değişimlerinin içsel ve dışsal bileşenleri arasında bir ayrıma gitmenin gerekli olmadığını belirtmişlerdir (Bernanke \& Mihov, 1998: 870).

Literatürde, açık ve kapalı ekonomilerde parasal aktarım mekanizmasının işleyişini VAR analizi kullanarak inceleyen çalışmaların bazılarında ampirik anormallikler tanımlanmıştır. Bu anormallikler literatürde fiyat ve döviz kuru puzzle'ı şeklinde açıklanmaktadır. Fiyat puzzle’ı (fiyat karışıklığı ya da muamması) faiz oranlarında meydana gelen bir şok karşısında fiyat düzeyinin azalması yerine artmasını ifade etmektedir (Sims, 1992). Döviz kuru puzzle’1 da (döviz kuru karışıklığı ya da muamması) faiz oranlarında meydana gelen pozitif bir şok karşısında, ulusal paranın, Amerikan doları (USD) karşısında değer kaybetmesi olarak tanımlanmaktadır (Sims, 1992; Grilli ve Roubini, 1995). Sims (1992), fiyat puzzle'nın faiz oranı şokunun fiyat artışına yol açan enflasyonist baskılara yol açmasına bağlı olabileceğini söyler. Sims (1992) ile Grilli ve Roubini (1995), aynı zamanda fiyat puzzle açıklamasının döviz kuru puzzle'nı da açıklayabileceğini ifade etmişlerdir. Sims ve Zha (1995) fiyat puzzle deyimini tanımlarken, beklenen enflasyon için gösterge niteliğinde kullanılan değişkenleri içeren eş zamanlı sınırlamalara sahip "Yapısal VAR" modelini önermişlerdir. Gorden ve Leeper (1994), Christiano ve diğerleri (1996) ile Sims ve Zha (1998) fiyat puzzle'nı açıklamak için 
gösterge niteliğindeki değişken olarak beklenen enflasyonu, VAR modeline dâhil etmişlerdir. Bunlara karşın Kim ve Roubini (2000), beklenen enflasyon için gösterge niteliğindeki değişken olarak dünya petrol fiyatını almışlardır. Sözü edilen nedenlerden ötürü bu çalışmanın uygulamasında West Texas Intermediate (WTI) ham petrol fiyatları, VAR modeline dâhil edilmiştir.

Türkiye'de 2000 yılında uygulanan “Enflasyonla Mücadele Programı’nın” para politikası stratejisi nominal döviz kuru çıpasına dayalıdır. İzlenilen bu stratejide ekonomik birimlerin beklentileri döviz kuru hareketlerine göre şekillenirken, fiyatlama davranışları da büyük ölçüde döviz kuruna endekslenmekte idi. Ancak, Şubat 2001 krizinden sonra Türkiye yapısal bir dönüşüm sürecine yönelmiştir. Bu doğrultuda, 25 Nisan 2001 tarihinde TCMB Kanunu'nda yapılan değişiklik ile TCMB'nin temel amacı "fiyat istikrarını sağlamak" biçiminde belirlenmiş ve "Güçlü Ekonomiye Geçiş Programı'nın" uygulanmasıyla birlikte fiyat istikrarına odaklanan TCMB, 2002 yılından itibaren "örtük enflasyon hedeflemesi"ne yönelerek kısa vadeli faiz oranlarını politika aracı olarak kullanmaya başlamıştır. 2006 yılından itibaren de "açık enflasyon hedeflemesi rejimi" uygulamasına geçilmiştir (TCMB, 2013: 9-10). TCMB'deki bu dönüşüm ve değişim Nisan 2001 'den itibaren araç bağımsızlığı ile güvence altına alınmıştır. Öte yandan küresel finans krizi sonrasında, TCMB'nın "fiyat isitkrarı" amacına 2010 yılında "finansal istikrar" amacı eklenmiştir.

\section{Literatür}

Para politikalarının etkileri konusunda iktisat literatüründe çok sayıda çalışma bulunmaktadır. Son yıllarda yapılmış çalışmalara aşağıdaki Tablo 1'de yer verilmiştir.

İncelenen çalışmalarda, ilgili ülkedeki merkez bankasının uyguladığı para politikalarının, yine o ülkenin makroekonomik değişkenleri üzerine etkisi ya da FED ve ECB gibi merkez bankalarının uyguladığı para politikalarının çeşitli ülkelerin makroekonomik değişkenleri üzerine etkileri incelenmiştir.

\section{Tablo: 1}

\section{Konu İle İlgili Literatür}

\begin{tabular}{|c|c|c|}
\hline Yazar-lar (yıl) & İncelenen Konu & Kullanılan Yöntem \\
\hline $\begin{array}{l}\text { Bernanke ve } \\
\text { Mihov (1998) }\end{array}$ & $\begin{array}{l}\text { Para politikasında meydana gelen şokların ve türetilen yeni politikaların makroekonomik etkileri } \\
\text { incelenmiştir. }\end{array}$ & VAR \\
\hline $\begin{array}{l}\text { Ehrmann vd. } \\
\text { (2003) }\end{array}$ & $\begin{array}{l}\text { Avrupa'da uygulanan para politikalarının etkisi incelenmiştir. Buna göre, parasal sıkılaştırma çıktıyı ve } \\
\text { fiyatları anlamlı bir şekilde düşürmektedir. Çıktıdaki düşüş geçici iken fiyatlardaki düşüş kalıcı olmaktadır. }\end{array}$ & VAR \\
\hline Peker (2007) & $\begin{array}{l}\text { Türkiye'de para politikasının reel etkileri incelenmiştir. Hem öngörülen hem de öngörülemeyen para } \\
\text { politikalarının reel etkilerinin olduğu sonucuna ulaşılmıştır. }\end{array}$ & VAR \\
\hline Chuku (2009) & $\begin{array}{l}\text { Nijerya'da para politikasında meydana gelen şokların çıktıya ve fiyat düzeyine etkisi araştırılmıştır. } \\
\text { Emisyon hacmi yönetiminin en etkili para politikası aracı olduğu sonucuna varılmıştır. }\end{array}$ & SVAR \\
\hline Borys vd. (2009) & $\begin{array}{l}\text { Çek Cumhuriyeti’nde para politikalarının ekonomi üzerindeki etkileri araştırılmıştır. Para politikasında } \\
\text { meydana gelen bir şokun ekonomik aktiviteyi ve fiyat düzeyini negatif etkilediği sonucuna ulaşılmışır. }\end{array}$ & VAR \\
\hline
\end{tabular}


Erer, E. \& D. Erer \& M. Çayır \& N.O. Altay (2016), “TCMB, FED ve ECB Para Politikalarının Türkiye Ekonomisi Üzerindeki Etkileri: 1994-2014 Dönemi Analizi”, Sosyoekonomi, Vol. 24(29), 285-305.

\begin{tabular}{|c|c|c|}
\hline Örnek (2009) & $\begin{array}{l}\text { Türkiye'de para politikasında meydana gelen şokların reel ekonomi ve fiyatlar üzerindeki etkisi } \\
\text { araştırılmıştır. Faiz oranı ve döviz kuru kanallarının çalıştığı sonucuna ulaşılmıştır. }\end{array}$ & VAR \\
\hline $\begin{array}{c}\text { Oktar ve } \\
\text { Dalyanc1 (2012) }\end{array}$ & $\begin{array}{l}\text { Türkiye'de para politikalarının ekonomik büyümeye etkisi incelenmiştir. Ekonomik büyümenin uzun } \\
\text { dönemde para politikası ile yönetilebileceği sonucuna ulaşıllmıştır. }\end{array}$ & $\begin{array}{l}\text { Eşbütünleşme } \\
\text { ve VAR }\end{array}$ \\
\hline Chua (2012) & $\begin{array}{l}\text { Malezya'da para politikasında meydana gelen bir şokun makroekonomik değişkenlere etkisi araştırılmıştır. } \\
\text { Finansal ve reel ekonomik değişkenlerin birbiriyle ters yönde hareket ettiği sonucuna ulaşılmıştır. }\end{array}$ & FAVAR \\
\hline $\begin{array}{l}\text { Cambazoğlu ve } \\
\text { Karaalp (2012) }\end{array}$ & $\begin{array}{l}\text { Türkiye'de para politikalarının istihdam ve çıtı üzerindeki etkisi araştırılmıştır. Para stokundaki } \\
\text { değişmelerin istihdam ve çıktı gibi reel değişkenler üzerinde etkili olduğu sonucuna ulaşılmıștır. }\end{array}$ & VAR \\
\hline $\begin{array}{c}\text { Galvao ve } \\
\text { Marcellino (2014) }\end{array}$ & Daraltıcı para politikalarının çıktıda ve fiyatlarda daha fazla etkiye sahip olduğu sonucuna ulaşılmıştır. & SB-ET-VAR \\
\hline Doğan (2012) & $\begin{array}{l}\text { Türkiye'de parasal aktarım mekanizması açısından faiz oranı kanalı incelenmiştir. Geleneksel aktarım } \\
\text { mekanizmasının çalıştığı sonucuna ulaşılmıştır. }\end{array}$ & VAR \\
\hline Bhuiyan (2012) & $\begin{array}{l}\text { Bangladeş'te para politikalarında meydana gelen şokların makroekonomik değişkenler üzerindeki etkisi } \\
\text { araştırılmıştır. Ulaşılan sonuçlara göre, likiditede ve döviz kurunda meydana gelen şokların etkisi } \\
\text { endüstriyel üretimde } 6 \text { ay gecikmeyle görülürken enflasyonda } 1 \text { yıldan daha fazla gecikmeyle ortaya } \\
\text { çımaktadır. }\end{array}$ & SVAR \\
\hline $\begin{array}{l}\text { Jannsen ve Klein } \\
\qquad(2011)\end{array}$ & $\begin{array}{l}\text { Finansal kriz sürecinde para politikalarının çıtı üzerindeki etkisi incelenmiştir. Kriz döneminde, kriz } \\
\text { olmayan döneme göre, genişletici para politikasının çıktıyı daha olumlu etkilediği ve toparlanma döneminde } \\
\text { ise aksine, para politikasının kriz olmayan döneme göre daha az etkili olduğu sonucuna ulaşılmıstır. }\end{array}$ & VAR \\
\hline Ziaei (2014) & $\begin{array}{l}\text { Körfez ülkelerinde para politikasında meydana gelen şokların toplam talep üzerinde yarattığı etki } \\
\text { incelenmiştir. Para politikasında meydana gelen şokların öncelikle yatırımları, daha sonra da GSYIH'yı } \\
\text { etkilediği sonucuna ulaşılmıştır. }\end{array}$ & SVAR \\
\hline $\begin{array}{c}\text { Munir ve } \\
\text { Qayyum (2014) }\end{array}$ & $\begin{array}{l}\text { Pakistan'da uygulanan para politikalarının makroekonomik değişkenlere etkisi incelenmiştir. Faiz } \\
\text { oranlarının fiyatları negatif etkilediği, bu nedenle faiz oranlarının enflasyonu kontrol etmede iyi bir } \\
\text { enstrüman olduğu sonucuna ulaşılmıştır. }\end{array}$ & FAVAR \\
\hline Kelilume (2014) & $\begin{array}{l}\text { Nijerya'da politika faiz oranı ile kısa vadeli ve uzun vadeli faiz oranları arasındaki ilişki araştırılmıştır. } \\
\text { Gelişmekte olan bir ülkeye göre, para politikasının daha etkin olduğu, ancak para piyasası araçlarının } \\
\text { gelişmemiş olduğu sonucuna ulaşılmıştır. }\end{array}$ & $\begin{array}{l}\text { VAR ve Granger } \\
\text { Nedensellik Testi }\end{array}$ \\
\hline
\end{tabular}

Sermaye hareketlerinin serbestleştiği, finansal derinleşme ve ekonomik küreselleşmenin teknolojinin de yardımı ile giderek hızlandığı göz önüne alındığında, ulusal ekonomilerin yalnızca ilgili ülkenin merkez bankasının uyguladığı politikalardan etkilenmesini beklemek tek başına anlamlı değildir. Bu noktadan hareketle, çalışmamızda Türkiye'deki makroekonomik değişkenleri sadece TCMB'nin uyguladığ politikalar açısından değil, ülke ekonomimizi etkileme gücünün en yüksek olduğunu düşündüğümüz iki güçlü merkez bankasının (FED ve ECB) uyguladığı politikalar açısından da inceledik.

$\mathrm{Bu}$ çalışmanın literatürdeki diğer çalışmalardan farkı, FED ile ECB'nin Euro Bölgesinde uyguladığı para politikalarının Türkiye ekonomisi üzerindeki etkilerini dikkate almakta ve uygulanan yöntem açısından literatüre katkı sağlamayı hedeflemektedir.

\section{Veri Seti ve Model}

$\mathrm{Bu}$ çalışmada, incelenen dönem içerisindeki reformların aktarım mekanizması üzerindeki etkisi Eşik Vektör Otoregresif Regresyon (TVAR-Threshold VAR) yöntemi (Tsay, 1998) ile ele alınmaktadır. TVAR yöntemi rejim değişimi, asimetri ve çoklu dengeler gibi doğrusal olmama durumunun elde edilmesinde kullanılan bir yöntemdir. Çalışmada TVAR yönteminin kullanılmasının nedeni, çoklu rejimlerin varlığının test edilmesi ve ekonominin bu rejimler arasında nasıl değiştiğini gösterebilmesidir. Dönem analizinde kullandığımız model Vespignani (2015) ile Çatık ve Martin (2012) çalışmalarından hareketle geliştirilmiştir. Çatık ve Martin (2012), 1986:1-2010:11 dönemi için sanayi üretim endeksi, tüketici fiyat endeksi, kısa dönem faiz oranı (interbank faiz 
oranı) ve toplam kredi hacmi değişkenlerine ait aylık veriler kullanarak parasal aktarım mekanizmasını TVAR yöntemi kullanarak tahmin etmişlerdir. Öte yandan Vespignani (2015), ABD, Japonya ve Çin'den gelen parasal bir şokun Euro bölgesi üzerindeki etkisini incelemek için 1999:1-2011:12 dönemi için aylık verilerle parasal büyüklükler, sanayi üretim endeksi, global emtia fiyat endeksi, WTI ham petrol fiyatı, reel efektif ticari ağırlıklı Euro para birimi ve sanayi üretim endeksi değişkenlerini kullanarak SVAR yöntemini uygulamıştır.

Çalışmada kullanılan doğrusal VAR modeli aşağıdaki gibi yazılabilir:

$$
Y_{t}=\sum_{i=1}^{p} A_{i} Y_{t-i}+\sum_{i=1}^{q} B_{i} X_{t-i}+\varepsilon_{t}
$$

Burada $Y_{t} \mathrm{t}$ dönemindeki içsel değişkenleri içeren bir vektördür.

$$
Y_{t}=\left[i_{\text {turkey }}, i_{\text {us }}, i_{\text {euro }}, \text { lnreer }, \text { lncpisa }, \text { lnip }\right]^{\prime}
$$

$X_{t}$, t zamanında dışsal değişkenleri içeren bir vektördür.

$$
X_{t}=[\operatorname{lnoil}]
$$

$\varepsilon_{t}, \mathrm{t}$ zamanında yapısal şoklar vektörüdür. A ve B katsayı matrisleridir. Aktarım mekanizması $\varepsilon_{t}$ 'deki şoklara karşı içsel değişkenlerin tepkisini tanımlayan etki-tepki fonksiyonları ile elde edilmektedir.

TVAR modeli (Atasanova, 2003; Balke, 2000) ekonominin iki rejime sahip olduğu ve eşik değişkenin değerine bağlı olarak rejimlerin birinden diğerine değiştiği VAR modelinin genişletilmiş halidir. TVAR modeli aşağıdaki gibi yazılabilir:

$Y_{t}=I\left[c_{t-d} \geq \gamma\right]\left(\sum_{i=1}^{p} A_{i}^{1} Y_{t-i}+\sum_{i=1}^{q} B_{i}^{1} X_{t-i}\right)+I\left[c_{t-d}<\gamma\right]\left(\sum_{i=1}^{p} A_{i}^{2} Y_{t-i}+\sum_{i=1}^{q} B_{i}^{2} X_{t-i}\right)+u_{t}$

Burada $c_{t-d}$ sistemin hangi rejimde olduğunu belirleyen eşik değişkeni ve $I\left[c_{t-d} \geq \gamma\right] \quad, \quad c_{t-d} \geq \gamma$ olduğunda 1 , aksi durumda 0 değerini alan gösterge fonksiyonudur. $\gamma$ eşik değeridir. $A_{i}^{1}, A_{i}^{2}, B_{i}^{1}$ ve $B_{i}^{2}$ rejim parametreleridir. Eşik değişkeni eşik değerine eşit olduğunda veya eşik değerini aştığında ekonomi rejim 'de, diğer durumda rejim 2'dedir.

Çalışmada 1994:1-2014:10 dönemi için aylık veriler kullanılmıştır. Ekonomik faaliyetin ölçümünde gayri safi yurtiçi hasılayı temsilen sanayi üretim endeksinden yararlanılmıştır. Kısa dönem faiz oranı için bankalararası faiz oranı (interbank rate) 
alınmıştır (Bkz. Kim ve Roubini, 2000; Berument, 2007; Çatık ve Martin, 2012). Fiyat düzeyi tüketici fiyat endeksi ile döviz kuru değişkeni reel efektif döviz kuru ile ölçülmüştür. Kim ve Roubini (2000) ile Kim (2001a; 2001b) çalışmalarında, FED'in enflasyonist şoklara ilişkin petrol fiyatına karşılık olarak para politikasını sıkılaştıracağ düşüncesinden hareketle faiz oranı denklemine petrol fiyatları eklenmiştir. $\mathrm{Bu}$ nedenle, çalışmamızda WTI ham petrol (crude oil) fiyatı dışsal değişken olarak modele yerleştirilmiştir. Türkiye'ye ilişkin bankalararası faiz oranı (kısa dönem rate), reel efektif döviz kuru endeksi, tüketici fiyat endeksi ve sanayi üretim endeksi değişkenleri ile ABD kısa dönem faiz oranı (kısa dönem rate) değişkenleri ve WTI ham petrol fiyatları "Federal Reserve of St. Louis (FRED)" veri tabanından alınmıştır. Euro bölgesindeki 11 ülkeye ilişkin kısa dönem faiz oranı verileri de "stats.oecd" veri tabanından elde edilmiştir.

Faiz oranları dışındaki tüm değişkenler hareketli ortalamalar yöntemiyle mevsimsellikten arındırıldıktan sonra doğal logaritmaları alınmıştır. Çalışmada kullanılan değişkenler ve açıklamaları Tablo 2'de yer almaktadır.

Tablo: 2

\section{Çalışmada Kullanılan Değişkenler ve Açıklamaları}

\begin{tabular}{|l|l|}
\hline Değişkenler & Açıklamaları \\
\hline ITURKEY & Türkiye'ye ilişkin bankalararası faiz oranı \\
\hline IUS & Amerika'ya ilişkin bankalararası faiz oranı \\
\hline IEURO & Euro Bölgesi'ne ilişkin bankalararası faiz oranı \\
\hline LNREER & Sanayi üretim endeksinin doğal logaritması \\
\hline LNCPISA & Tüketici fiyat endeksinin doğal logaritması \\
\hline LNIP & Reel efektif döviz kuru endeksinin doğal logaritması \\
\hline LNOIL & WTI ham petrol fiyatının doğal logaritması \\
\hline
\end{tabular}

Değişkenlere ait özet istatistikler aşağıdaki Tablo 3'de yer almaktadır.

Tablo: 3

\section{Özet İstatistikler}

\begin{tabular}{|l|c|c|c|c|c|c|c|}
\hline & ITURKEY & IUS & IEURO & LNREER & LNCPISA & LNIP & LNOIL \\
\hline Mean & 41.12033 & 3.224239 & 2.812760 & 4.373631 & 3.359477 & 4.384397 & 3.720600 \\
\hline Median & 22.00000 & 3.272950 & 3.040000 & 4.420253 & 4.095329 & 4.391783 & 3.653481 \\
\hline Maximum & 400.2700 & 6.790140 & 6.840000 & 4.659150 & 4.935347 & 4.861927 & 4.887211 \\
\hline Minimum & 1.500000 & 0.226090 & 0.000000 & 3.866885 & -0.814285 & 3.864521 & 2.481085 \\
\hline Std. Dev. & 48.13334 & 2.315116 & 1.855185 & 0.176505 & 1.583366 & 0.253083 & 0.681487 \\
\hline Skewness & 3.707827 & -0.048542 & 0.078926 & -0.650770 & -1.103176 & 0.023804 & -0.021100 \\
\hline Kurtosis & 23.78027 & 1.348425 & 2.096460 & 2.513298 & 2.938479 & 1.802556 & 1.547781 \\
\hline Jarque-Bera & 5070.953 & 28.51173 & 8.763553 & 20.11339 & 50.74763 & 14.95978 & 21.98667 \\
\hline Probability & 0.000000 & 0.000001 & 0.012503 & 0.000043 & 0.000000 & 0.000564 & 0.000017 \\
\hline Observations & 250 & 250 & 250 & 250 & 250 & 250 & 250 \\
\hline
\end{tabular}




\section{Ampirik Sonuçlar}

Etki-tepki fonksiyonları ve varyans ayrıştırması analizine geçmeden önce, değişkenlerin durağanlıklarının araştırılması gerekmektedir. Tablo 3'de değişkenlerin düzey ve birinci farkları için ADF ve Philips-Perron test sonuçları yer almaktadır. Tablo 4'deki sonuçlara göre, iturkey değişkeni dışındaki tüm değişkenlerin 0.05 önem seviyesinde birinci farklarında durağan oldukları gözlenmektedir. iturkey değişkeni, ADF testine göre birinci farkında durağan iken, Philips-Perron testine göre düzey değerinde durağandır. Örnek hacmi 1996-1997 Güneydoğu Asya ve Doğu Asya, 1998 Rusya, Kasım 2000 - Şubat 2001 ve 2008 - 2009 ekonomik krizlerini içerdiği için yapısal kırılmaların varlığını görmek amacıyla Lee and Strazicich (2003) birim kök testi uygulamıştır. Bu testte sıfir hipotezinin reddedilmesi değişkenlerin trend durağan olduğunu göstermektedir. Değişkenlerin düzey ve birinci farkları için uygulanan iki kırılmalı LM testi sonuçları kırılma tarihleri ile birlikte Tablo 5'de gösterilmiştir. Perron (1989) doğrultusunda, Model A düzeydeki değişimi, Model C düzey ve trenddeki değişimi dikkate almaktadır. Kritik değerler Lee ve Strazicich (2003) çalışmasından elde edilmiştir.

Tablo: 4

Augmented Dickey-Fuller ve Philips-Perron Birim Kök Testleri

\begin{tabular}{|c|c|c|c|c|c|}
\hline & & \multicolumn{2}{|l|}{ Düzzy Değerleri } & \multicolumn{2}{|l|}{ Birinci farkları } \\
\hline & & $\mathrm{t}$ istatistiği & p değeri & $\mathrm{t}$ istatistiği & p değeri \\
\hline \multirow[t]{2}{*}{ iturkey } & ADF & -2.543411 & 0.1065 & -10.47120 & 0.0000 \\
\hline & PP & -6.326227 & 0.0000 & -72.18965 & 0.0001 \\
\hline \multirow[t]{2}{*}{ ius } & ADF & -2.261908 & 0.1854 & -3.833886 & 0.0030 \\
\hline & $\begin{array}{l}\mathrm{PP} \\
\end{array}$ & $\begin{array}{l}-1.010994 \\
\end{array}$ & 0.7498 & $\begin{array}{l}-11.59812 \\
\end{array}$ & 0.0000 \\
\hline \multirow[t]{2}{*}{ ieuro } & ADF & -1.635667 & 0.4628 & -7.927816 & 0.0000 \\
\hline & PP & -1.747936 & 0.4059 & -14.11633 & 0.0000 \\
\hline \multirow[t]{2}{*}{ Inreer } & ADF & -2.360462 & 0.1542 & -10.55659 & 0.0000 \\
\hline & $\begin{array}{l}\mathrm{PP} \\
\end{array}$ & -2.015268 & 0.2802 & -11.46419 & 0.0000 \\
\hline \multirow[t]{2}{*}{ lncpi } & ADF & 0.503919 & 0.8237 & -8.699499 & 0.0000 \\
\hline & PP & 1.952570 & 0.9880 & -9.353124 & 0.0000 \\
\hline \multirow[t]{2}{*}{ Inip } & $\mathrm{ADF}$ & -0.667892 & 0.8513 & -16.28125 & 0.0000 \\
\hline & PP & -0.886853 & 0.7913 & -33.18735 & 0.0001 \\
\hline \multirow[t]{2}{*}{ Inoil } & ADF & -1.397626 & 0.5833 & -12.36296 & 0.0000 \\
\hline & $\mathrm{PP}$ & -1.325364 & 0.6182 & -12.38282 & 0.0000 \\
\hline
\end{tabular}

Not: Gecikme saylsı ADF birim kök testi için Akaike Bilgi Kriteri (AIC)'ne, Philips-Perron ve KPSS birim kök testlerinde ise Newey-West genişleme bandina göre belirlenmiştir.

Lee-Strazicich birim kök test sonuçları incelendiğinde, iturkey değişkeni düzey değerinde durağan iken, diğer tüm değişkenlerin birinci farklarında durağan hale geldikleri görülmektedir. Test sonucundan elde edilen kırılma tarihleri, Türkiye'de ve dünyada meydana gelen kriz dönemlerin Türkiye'deki makroekonomik değişkenler üzerinde önemli etkilere sahip olduğunu göstermektedir. Modelin tahmin aşamasına geçmeden önce, çoklu rejimlerin varlığını test etmek amacıyla Tsay (1998) tarafından önerilen C(d) istatistikleri kullanılmıştır. Gecikme parametreleri d ile $\mathrm{m}_{0}=25$ ve $\mathrm{m}_{0}=50$ alternatif başlangıç noktalarını kullanan yinelemeli regresyon tahminine dayanan $\mathrm{C}(\mathrm{d})$ eşik (threshold) doğrusalsızlık test sonuçları Tablo 6'da verilmiştir. Test sonuçları tüm gecikmeler için 
modelin doğrusal olduğunu söyleyen sıfir hipotezinin 0.01 anlamlllık düzeyinde her bir alternatif eşik (threshold) için reddedildiğini göstermektedir. Bu sonuç doğrusal VAR modeline karşı TVAR lehine güçlü bir kanıt sağlamakta ve TÜFE'deki değişmelerle verilen iki rejimin varlığını desteklemektedir. Threshold testi eşik (threshold) değişkeni $\Delta$ lncpi için maksimum delay parametresini $\chi^{2}$ test istatistiği değerine sahip olan $(275.61$ ve 250.22) $\mathrm{d}=1$ olarak seçmiştir. Bu d değeri için minimum Akaike Bilgi Kriterine (AIC) sahip olan grid, $\gamma=\% 2.783$ olduğunda elde edilmektedir. Bu sonuçlara göre, Rejim 1 $\Delta$ lncpi $\geq \% 2.783$ olduğundan yüksek enflasyon dönemini, Rejim 2, threshold değişkeni $\Delta$ lncpi'in optimal threshold değeri \%2.783'den küçük olduğu dönemi kapsadığından düşük enflasyon rejimi ifade etmektedir.

Tablo: 5

İki Kırılmalı Lee-Strazicich Birim Kök Testi

\begin{tabular}{|c|c|c|c|c|c|c|c|c|c|c|c|c|}
\hline \multicolumn{5}{|c|}{ Model A(sabit terimli) } & \multirow{3}{*}{$\begin{array}{l}\text { Kritik } \\
\text { Değerle }\end{array}$} & \multicolumn{6}{|c|}{ Model C(sabit ve trendli) } & \multirow{3}{*}{$\begin{array}{l}\text { Kritik } \\
\text { Değerle }\end{array}$} \\
\hline & \multirow[t]{2}{*}{$L M$} & \multirow[t]{2}{*}{ Gecikme } & \multicolumn{2}{|c|}{ Kirılma Zamanları } & & \multirow[t]{2}{*}{$L M$} & \multirow[t]{2}{*}{ Gecikme } & \multicolumn{4}{|c|}{ Kirlma Zamanlart } & \\
\hline & & & $D_{1 t}$ & $\mathrm{D}_{2 \mathrm{t}}$ & & & & $\mathrm{D}_{1 \mathrm{t}}$ & $\mathrm{DT}_{1 \mathrm{t}}$ & $\mathrm{D}_{21}$ & $\mathrm{DT}_{2 \mathrm{t}}$ & \\
\hline Iturkey & -8.7052 & 2 & $2001: 4$ & $2003: 7$ & -3.842 & -10.4089 & 2 & $2001: 4$ & $2001: 4$ & $2003: 1$ & $2003: 1$ & -5.59 \\
\hline Aiturkey & -3.9794 & 7 & 1996:12 & $2001: 4$ & -3.842 & -11.0485 & 7 & $2000: 12$ & $2000: 12$ & $2002: 12$ & $2002: 12$ & -5.59 \\
\hline İus & -2.0961 & 1 & $2001: 4$ & $2008: 10$ & -3.842 & -2.9087 & 2 & $2002: 2$ & $2002: 2$ & $2008: 10$ & $2008: 10$ & -5.67 \\
\hline Aius & -3.9288 & 10 & $2002: 11$ & $2009: 6$ & -3.842 & -6.5581 & 10 & $2008: 10$ & $2008: 10$ & $2010: 11$ & $2010: 11$ & -5.59 \\
\hline İeuro & -3.8301 & 2 & $2006: 5$ & $2009: 5$ & -3.842 & -3.3701 & 2 & $2006: 5$ & $2006: 5$ & $2009: 5$ & $2009: 5$ & -5.73 \\
\hline Aieuro & -6.0300 & 9 & $2000: 10$ & 2007:11 & -3.842 & -7.1673 & 9 & $2008: 6$ & $2008: 6$ & $2010: 10$ & 2010:10 & -5.73 \\
\hline Lnreer & -2.6290 & 12 & 2001:11 & $2005: 5$ & -3.842 & -4.7233 & 2 & $1997: 5$ & $1997: 5$ & $2011: 3$ & $2011: 3$ & -5.71 \\
\hline Alnreer & -4.4661 & 11 & $2001: 5$ & $2008: 8$ & -3.842 & -7.8846 & 11 & $2001: 4$ & $2001: 4$ & $2003: 3$ & $2003: 3$ & -5.67 \\
\hline Lncpi & -3.1899 & 5 & 1997:5 & $2011: 3$ & -3.842 & -3.9084 & 5 & 1998:9 & 1998:9 & $2002: 12$ & $2002: 12$ & -5.59 \\
\hline Alncpi & -5.5524 & 4 & $2002: 1$ & $2007: 10$ & -3.842 & -8.0591 & 4 & $2001: 3$ & $2001: 3$ & $2004: 5$ & $2004: 5$ & -5.67 \\
\hline Lnip & -3.8053 & 12 & $2003: 11$ & $2008: 12$ & -3.842 & -4.8392 & 12 & $2000: 8$ & $2000: 8$ & $2005: 12$ & $2005: 12$ & -5.67 \\
\hline Alnip & -3.9203 & 12 & $2002: 8$ & $2008: 2$ & -3.842 & 12.7622 & 12 & $2000: 9$ & $2000: 9$ & $2007: 11$ & $2007: 11$ & -5.67 \\
\hline Lnoil & -3.2356 & 1 & $1996: 4$ & $2004: 9$ & -3.842 & -4.9950 & 2 & 1997:10 & 1997:10 & $2004: 11$ & $2004: 11$ & -5.74 \\
\hline Alnoil & -12.9346 & 0 & 2001:10 & $2008: 10$ & -3.842 & -12.8905 & 0 & $2008: 7$ & $2008: 7$ & $2010: 8$ & $2010: 8$ & \begin{tabular}{|l|}
-5.73 \\
\end{tabular} \\
\hline
\end{tabular}

Not: : LS testinde Model A sabitli, Model C sabitli ve trendli modellerdir. Kritik değerler Lee and Strazicich (2003)'den elde edilmiştir. ${ }^{* *} 0.05$ önem seviyesindeki anlamlılık düzeyini göstermektedir.

Tablo: 6

\section{Threshold Doğrusalsızlık Test Sonuçları}

\begin{tabular}{|l|l|l|l|l|l|l|l|}
\hline $\mathbf{d}$ & $\mathbf{m}_{\mathbf{0}}$ & $\mathbf{C}(\mathbf{d})$ & prob. & $\mathbf{D}$ & $\mathbf{m}_{\mathbf{0}}$ & $\mathbf{C}(\mathbf{d})$ & prob. \\
\hline 1 & 25 & 275.61 & 0.00000 & 4 & 25 & 178.06 & 0.00000 \\
\hline 1 & 50 & 250.22 & 0.00000 & 4 & 50 & 168.27 & 0.00000 \\
\hline 2 & 25 & 220.32 & 0.00000 & 5 & 25 & 128.89 & 0.00026 \\
\hline 2 & 50 & 213.78 & 0.00000 & 5 & 50 & 122.61 & 0.00095 \\
\hline 3 & 25 & 150.61 & 0.00000 & 6 & 25 & 261.24 & 0.00000 \\
\hline 3 & 50 & 142.41 & 0.00001 & 6 & 50 & 237.65 & 0.00000 \\
\hline$\gamma=0.02783 \quad \mathrm{AIC}=-1684.23220$ &
\end{tabular}

Şekil 1'de çalışmada eşik değişken olarak alınan enflasyon oranı için rejim sınıflandırmasına ilişkin grafik yer almaktadır. 


\section{Şekil: 1 \\ Rejim Sınıflandırması}

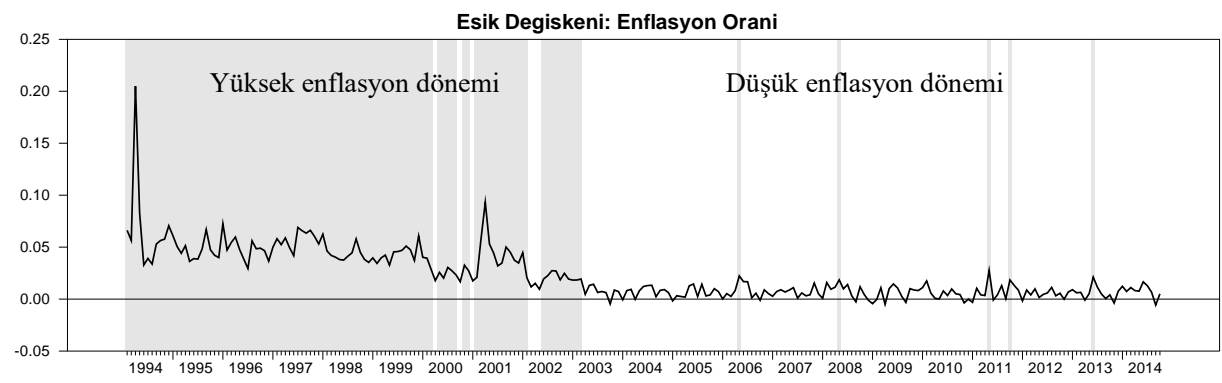

TCMB, FED ve ECB kısa dönem faiz oranlarında meydana gelen bir standart hatalık şok karşısında değiş̧enlerin verdiği tepkiler düşük enflasyon ve yüksek enflasyon dönemleri açısından sırasıyla açıklanmaktadır. Bunlara ilişkin çıktıların grafik gösterimleri çalışmanın sonunda ek olarak gösterilmektedir.

Doğrusal VAR modelinde, TCMB kısa dönem faiz oranındaki bir standart sapmalık şok karşısında reel efektif döviz kuru ilk üç ay boyunca azalmakta, 4. ayda artmakta ve 5. aydan itibaren bu etki anlamsız hale gelmektedir. Diğer taraftan FED kısa dönem faiz oranı karşısında ilk 3 ay, ECB kısa dönem faiz oranı karşısında da sadece ilk ay pozitif ve anlamlı bir tepki vermektedir. Sanayi üretim endeksi, TCMB kısa dönem faiz oranı karşısında reel efektif döviz kuruna benzer bir tepki vermekle birlikte etkisi daha kısa sürmektedir. FED kısa dönem faiz oranındaki bir standart hatalık şok karşısında sadece 1 . ay pozitif, ECB kısa dönem faiz oranı karşısında ise 6. ayda negatif bir tepki göstermektedir. CPI, TCMB kısa dönem faiz oranı karşısında pozitif ve zaman içinde azalan bir tepki gösterirken, FED kısa dönem faiz oranı karşısında 3. aydan itibaren anlamlı negatif bir tepki göstermektedir.

Yüksek enflasyon rejimi dikkate alındığında, TCMB kısa dönem faiz oranındaki bir standart hatalık değişim karşısında reel döviz kuru sadece 3. ayda pozitif ve anlamlı bir tepki verirken, sanayi üretim endeksinin tepkisi doğrusal VAR modeliyle benzerdir. $\mathrm{Bu}$ dönemde, FED kısa dönem faiz oranı sadece reel efektif döviz kuru üzerinde 2. ve 4. aylar arasında pozitif ve anlamlı bir etkiye sahiptir. Düşük enflasyon dönemi açısından incelendiğinde, TCMB kısa dönem faiz oranındaki bir standart hatalık şok, reel döviz kurunu pozitif, tüketici fiyat endeksini ilk 4 ay pozitif, sonraki 2 ay negatif ve son olarak sanayi üretim endeksini de bir ay negatif bir ay pozitif olacak şekilde etkilemektedir. Elde edilen sonuç, Türkiye'de daraltıı para politikası şokunun fiyatlar ve döviz kurunu azalttığını söyleyen fiyat ve döviz kuru puzzle görüşünün geçerli olduğunu göstermektedir. 
Bunun nedeni, Türkiye'de üretim maliyetlerinin döviz kuruna duyarlılığının yüksek olmasından kaynaklanabilir.

Düşük enflasyon döneminde FED kısa dönem faiz şokları karşısında reel efektif döviz kurunun tepkisi ilk 3 ay boyunca pozitif, sonraki 3 ay negatif iken, ECB kısa dönem faiz şoku karşısında 2. ve 5. ay arasında negatif bir etkiye sahiptir. Sanayi üretim endeksi ve TÜFE birbirlerine benzer olarak FED kısa dönem faiz şoku karşısında ilk ay pozitif, 2. ay negatif bir tepki göstermişlerdir. ECB faiz şoku karşısında TÜFE pozitif bir tepki vermektedir ve bu etki uzun sürelidir. Buna karşın sanayi üretim endeksi üzerinde ilk 3 ay pozitif, daha sonra 6 . aya kadar dalgalı bir seyir izlemektedir.

Tablo: 7

\section{Sanayi Üretim Endeksine Ait Varyans Ayrıştırma Sonuçları}

\begin{tabular}{|c|c|c|c|c|c|c|c|c|c|c|c|c|c|c|}
\hline \multirow{2}{*}{\multicolumn{15}{|c|}{$\begin{array}{l}\text { Sanayi Üretim Endeksi } \\
\text { TCMB }\end{array}$}} \\
\hline & & & & & & & & & & & & & & \\
\hline & \multicolumn{4}{|c|}{ Doğrusal VAR } & & \multicolumn{4}{|l|}{ Rejim 1} & & \multicolumn{4}{|l|}{ Rejim2 } \\
\hline & Dlnip & dlncpisa & diturkey & Dlnreer & & dlnip & dlncpisa & diturkey & Dlnreer & & dlnip & dlncpisa & diturkey & dlnreer \\
\hline 1 & 100.00 & 0.000 & 0.000 & 0.000 & 1 & 100.000 & 0.000 & 0.000 & 0.000 & 1 & 100.000 & 0.000 & 0.000 & 0.000 \\
\hline 2 & 94.544 & 0.396 & 5.053 & 0.007 & 2 & 94.685 & 0.026 & 5.080 & 0.210 & 2 & 95.808 & 0.105 & 3.980 & 0.107 \\
\hline 4 & 90.895 & 1.271 & 6.405 & 1.429 & 4 & 82.108 & 2.978 & 7.95888 & 6.957 & 4 & 94.374 & 0.205 & 4.319 & 1.102 \\
\hline 6 & 90.473 & 1.291 & 6.418 & 1.818 & 6 & 80.892 & 4.264 & 7.930 & 6.914 & 6 & 94.213 & 0.254 & 4.345 & 1.187 \\
\hline 12 & 90.144 & 1.391 & 6.584 & 1.883 & 12 & 80.813 & 4.269 & 7.975 & 6.942 & 12 & 94.187 & 0.257 & 1.198 & 4.356 \\
\hline 18 & 90.129 & 1.395 & 6.591 & 1.885 & 18 & 80.812 & 4.269 & 7.975 & 6.942 & 18 & 94.187 & 0.257 & 1.198 & 4.356 \\
\hline 24 & 90.129 & 1.395 & 6.591 & 1.885 & 24 & 80.812 & 4.269 & 7.975 & 6.942 & 24 & 94.187 & 0.257 & 1.198 & 4.356 \\
\hline \multicolumn{15}{|c|}{ FED } \\
\hline & \multicolumn{4}{|c|}{ Doğrusal VAR } & & \multicolumn{4}{|l|}{ Rejim 1} & & \multicolumn{4}{|l|}{ Rejim2 } \\
\hline & Dlnip & dlncpisa & Dius & Dlnreer & & dlnip & dlncpisa & dius & Dlnreer & & dlnip & dlncpisa & dius & dlnreer \\
\hline 1 & 100.00 & 0.000 & 0.000 & 0.000 & 1 & 100.000 & 0.000 & 0.000 & 0.000 & 1 & 100.000 & 0.000 & 0.000 & 0.000 \\
\hline 2 & 98.114 & 0.374 & 1.215 & 0.297 & 2 & 98.962 & 0.821 & 0.079 & 0.138 & 2 & 97.382 & 0.421 & 1.618 & 0.579 \\
\hline 4 & 97.002 & 0.626 & 1.276 & 1.096 & 4 & 84.461 & 4.042 & 2.926 & 8.571 & 4 & 96.071 & 0.943 & 2.254 & 0.733 \\
\hline 6 & 96.574 & 0.624 & 1.621 & 1.181 & 6 & 82.998 & 4.338 & 3.573 & 9.091 & 6 & 95.567 & 1.142 & 2.377 & 0.913 \\
\hline 12 & 96.563 & 0.630 & 1.622 & 1.185 & 12 & 82.807 & 4.354 & 3.627 & 9.213 & 12 & 95.561 & 1.148 & 2.376 & 0.916 \\
\hline 18 & 96.563 & 0.630 & 1.622 & 1.185 & 18 & 82.806 & 4.354 & 3.627 & 9.213 & 18 & 95.561 & 1.148 & 2.376 & 0.916 \\
\hline 24 & 96.563 & 0.630 & 1.622 & 1.185 & 24 & 82.806 & 4.354 & 3.627 & 9.213 & 24 & 95.561 & 1.148 & 2.376 & 0.916 \\
\hline \multicolumn{15}{|c|}{ ECB } \\
\hline & \multicolumn{4}{|c|}{ Doğrusal VAR } & & \multicolumn{4}{|l|}{ Rejim 1} & & \multicolumn{4}{|l|}{ Rejim2 } \\
\hline & Dlnip & dlncpisa & Dieuro & dlnreer & & dlnip & dlncpisa & dieuro & Dlnreer & & dlnip & dlncpisa & dieuro & dlnreer \\
\hline 1 & 100.00 & 0.000 & 0.000 & 0.000 & 1 & 100.000 & 0.000 & 0.000 & 0.000 & 1 & 100.000 & 0.000 & 0.000 & 0.000 \\
\hline 2 & 99.105 & 0.354 & 0.385 & 0.246 & 2 & 99.146 & 0.299 & 0.291 & 0.264 & 2 & 98.939 & 0.452 & 0.467 & 0.142 \\
\hline 4 & 97.746 & 0.608 & 0.495 & 1.151 & 4 & 89.723 & 2.385 & 0.975 & 6.918 & 4 & 97.870 & 0.828 & 0.950 & 0.351 \\
\hline 6 & 97.712 & 0.609 & 0.498 & 1.180 & 6 & 88.498 & 2.420 & 1.259 & 6.825 & 6 & 97.108 & 1.121 & 1.312 & 0.460 \\
\hline 12 & 97.706 & 0.611 & 0.501 & 1.182 & 12 & 88.352 & 2.468 & 2.326 & 6.854 & 12 & 97.092 & 1.129 & 1.317 & 0.462 \\
\hline 18 & 97.706 & 0.611 & 0.501 & 1.182 & 18 & 88.352 & 2.468 & 2.326 & 6.854 & 18 & 97.092 & 1.129 & 1.317 & 0.462 \\
\hline 24 & 97.706 & 0.611 & 0.501 & 1.182 & 24 & 88.352 & 2.468 & 2.326 & 6.854 & 24 & 97.092 & 1.129 & 1.317 & 0.462 \\
\hline
\end{tabular}

Yukarıdaki Tablo 7, sanayi üretim endeksi için tahmin edilen varyans ayrıştırmalarını göstermektedir. Yüksek enflasyon döneminde (Rejim 1), reel döviz kuru, TCMB kısa dönem faiz oranı ve tüketici fiyat endeksi şoklarının etkisi düşük enflasyon dönemine göre (Rejim 2) çok daha büyüktür. Öyle ki, 2 yıllık bir dönemde, bu şokların toplam etkisi Rejim 1'de çıktıdaki değişimin \%19'unu, Rejim 2'de sadece \%6'sını açıklamaktadır. FED ve ECBfaiz oranı şoklarının çıktıdaki değişim üzerindeki toplam etkisi Rejim 1'de, Rejim 2'ye göre daha yüksektir. 
Tüketici fiyat endeksi için tahmin edilen varyans ayrıştırma sonuçları Tablo 8'de yer almaktadır. Gerek yüksek enflasyon dönemini gösteren Rejim 1'de, gerekse düşük enflasyon dönemi olan Rejim 2'de fiyattaki varyansı en yüksek reel döviz kurunda meydana gelen şoklar açıklamaktadır. Ayrıca, FED faiz şoku TÜFE'deki değişimi Rejim 1'de daha yüksek açıklarken, ECB faiz şokunun TÜFE üzerindeki etkisi Rejim 2'de daha fazladır. Yüksek enflasyon döneminde FED'in etkisinin daha yüksek, düşük enflasyon döneminde ise ECB'nin etkisinin daha yüksek olmasının nedeni, Türkiye'de maliyetlerin USD cinsinden, satışların da EURO cinsinden olması şeklinde açıklanabilir.

Tablo: 8

Tüketici Fiyat Endeksine Ait Varyans Ayrıştırma Sonuçları

\begin{tabular}{|c|c|c|c|c|c|c|c|c|c|c|c|c|c|c|}
\hline \multicolumn{15}{|c|}{ Tüketici Fiyat Endeksi } \\
\hline \multicolumn{15}{|c|}{ TCMB } \\
\hline & \multicolumn{4}{|c|}{ Doğrusal VAR } & & \multicolumn{4}{|c|}{ Rejim 1} & & \multicolumn{4}{|c|}{ Rejim2 } \\
\hline & dlnip & dlncpisa & Diturkey & Dlnreer & & Dlnip & dlncpisa & diturkey & dlnreer & & dlnip & dlncpisa & diturkey & dlnreer \\
\hline 1 & 0.043 & 99.957 & 0.000 & 0.000 & 1 & 0.876 & 99.124 & 0.000 & 0.000 & 1 & 0.472 & 99.528 & 0.000 & 0.000 \\
\hline 2 & 0.039 & 93.280 & 2.438 & 4.242 & 2 & 0.824 & 97.328 & 0.003 & 1.845 & 2 & 0.681 & 90.845 & 2.289 & 6.186 \\
\hline 4 & 0.188 & 82.942 & 7.775 & 9.095 & 4 & 1.012 & 94.850 & 0.779 & 3.360 & 4 & 0.875 & 83.893 & 5.664 & 9.568 \\
\hline 6 & 0.367 & 81.775 & 8.173 & 9.685 & 6 & 1.052 & 94.294 & 0.794 & 3.860 & 6 & 0.877 & 85.262 & 5.620 & 8.240 \\
\hline 12 & 1.321 & 80.023 & 8.958 & 9.698 & 12 & 1.055 & 94.205 & 0.805 & 3.935 & 12 & 0.933 & 86.045 & 5.406 & 7.616 \\
\hline 18 & 1.558 & 79.448 & 9.215 & 9.778 & 18 & 1.055 & 94.205 & 0.805 & 3.935 & 18 & 0.945 & 86.329 & 7.378 & 5.347 \\
\hline 24 & 1.691 & 79.113 & 9.359 & 9.838 & 24 & 1.055 & 94.205 & 0.805 & 3.935 & 24 & 0.945 & 86.329 & 7.378 & 5.347 \\
\hline \multicolumn{15}{|c|}{ FED } \\
\hline & \multicolumn{4}{|c|}{ Doğrusal VAR } & & \multicolumn{4}{|c|}{ Rejim 1} & & \multicolumn{4}{|c|}{ Rejim2 } \\
\hline & dlnip & dlncpisa & Dius & Dlnreer & & Dlnip & dlncpisa & dius & dlnreer & & dlnip & dlncpisa & Dius & dlnreer \\
\hline 1 & 0.048 & 99.952 & 0.000 & 0.000 & 1 & 0.164 & 99.836 & 0.000 & 0.000 & 1 & 0.000 & 100.000 & 0.000 & 0.000 \\
\hline 2 & 0.342 & 97.838 & 0.402 & 1.419 & 2 & 0.296 & 97.925 & 0.019 & 1.759 & 2 & 0.469 & 96.647 & 0.045 & 2.839 \\
\hline 4 & 2.988 & 92.073 & 2.312 & 2.628 & 4 & 0.743 & 92.982 & 2.538 & 3.737 & 4 & 0.675 & 91.641 & 0.051 & 7.633 \\
\hline 6 & 3.382 & 90.445 & 3.431 & 2.741 & 6 & 0.937 & 90.588 & 2.738 & 5.737 & 6 & 0.731 & 90.993 & 0.119 & 8.157 \\
\hline 12 & 3.884 & 88.369 & 5.494 & 2.253 & 12 & 0.967 & 90.295 & 2.752 & 5.986 & 12 & 0.734 & 90.754 & 0.138 & 8.374 \\
\hline 18 & 4.011 & 87.743 & 6.112 & 2.134 & 18 & 0.968 & 90.291 & 2.753 & 5.988 & 18 & 0.734 & 90.742 & 0.138 & 8.386 \\
\hline 24 & 4.050 & 87.552 & 6.301 & 2.098 & 24 & 0.968 & 90.291 & 2.753 & 5.988 & 24 & 0.734 & 90.742 & 0.138 & 8.386 \\
\hline \multicolumn{15}{|c|}{ ECB } \\
\hline & \multicolumn{4}{|c|}{ Doğrusal VAR } & & \multicolumn{4}{|c|}{ Rejim 1} & & \multicolumn{4}{|l|}{ Rejim2 } \\
\hline & dlnip & dlncpisa & Dieuro & Dlnreer & & Dlnip & dlncpisa & dieuro & dlnreer & & dlnip & dlncpisa & dieuro & dlnreer \\
\hline 1 & 0.036 & 99.964 & 0.000 & 0.000 & 1 & 0.185 & 99.815 & 0.000 & 0.000 & 1 & 0.018 & 99.982 & 0.000 & 0.000 \\
\hline 2 & 0.197 & 98.562 & 0.024 & 1.218 & 2 & 0.533 & 98.375 & 0.000 & 1.092 & 2 & 0.447 & 96.637 & 0.428 & 2.487 \\
\hline 4 & 1.855 & 94.517 & 0.888 & 2.739 & 4 & 0.907 & 93.797 & 1.373 & 3.923 & 4 & 0.580 & 92.849 & 0.586 & 5.985 \\
\hline 6 & 2.294 & 93.193 & 1.341 & 3.173 & 6 & 0.906 & 92.473 & 1.394 & 5.226 & 6 & 0.821 & 88.133 & 3.442 & 7.604 \\
\hline 12 & 2.819 & 92.222 & 2.039 & 2.846 & 12 & 0.918 & 92.403 & 1.424 & 5.225 & 12 & 0.963 & 85.141 & 6.154 & 7.743 \\
\hline 18 & 2.967 & 92.005 & 2.246 & 2.781 & 18 & 0.919 & 92.402 & 1.424 & 5.225 & 18 & 0.986 & 85.694 & 6.581 & 7.739 \\
\hline 24 & 3.104 & 91.912 & 2.312 & 2.761 & 24 & 0.919 & 92.402 & 1.424 & 5.225 & 24 & 0.988 & 844.659 & 6.614 & 7.738 \\
\hline
\end{tabular}

Son olarak aşağıdaki Tablo 9, reel döviz kuru için tahmin edilen varyans ayrıştırmalarını göstermektedir. Buna göre, reel döviz kurundaki değişimler üzerinde her iki rejimde de TCMB, FED ve ECB faiz oranı şoklarının etkisi oldukça yüksek olmasına rağmen, bu etki yüksek enflasyon dönemlerinde (Rejim 1), düşük enflasyon dönemlerine (Rejim 2'ye) göre daha fazladır. Öyle ki model, Rejim 1'de reel döviz kurunda meydana gelen değişmelerin \%20'sini, Rejim 2'de \%14'ünü açıklamaktadır. Bununla birlikte, sanayi üretim endeksinde meydana gelen şokun reel döviz kuru varyansı üzerindeki etkisi Rejim 1'de oldukça fazla iken, Rejim 2'de bu etki çok düşüktür. 
Tablo: 9

Reel Döviz Kuruna Ait Varyans Ayrıştırma Sonuçları

\begin{tabular}{|l|l|l|l|l|l|l|l|l|l|l|l|l|l|l|}
\hline \multicolumn{10}{|l|}{ Reel Döviz Kuru } \\
\hline \multicolumn{9}{|l|}{ TCMB } \\
\hline
\end{tabular}

\section{Sonuç}

Bağımsız merkez bankalarının para politikaları uygulamaları, ilgili ülke ve/veya ülkeler grubundaki ekonomik istikrarın sağlanması açısından yaşamsal öneme sahiptir. Bu nedenle gerek kriz, gerekse durgunluk dönemlerinin hafif atlatılabilmesi amaciyla uygun para politikalarının doğru zamanlarda ve doğru araçlarla uygulanması gerekir.

TCMB, FED ve ECB para politikaları şokları üzerinden yürüttüğü politikaların Türkiye'de ekonomik faaliyet üzerindeki etkileri bu çalışmada yüksek ve düşük enflasyon dönemleri dikkate alınarak analiz edilmiştir. Sonuçlar, düşük enflasyon döneminde Türkiye'de para politikası şokunun fiyatlar ve reel döviz kuru üzerinde bir artışa neden olduğunu, yüksek enflasyon döneminde herhangi bir etkiye sahip olmadığını göstermektedir. Elde edilen sonuçlar Sims (1992), Grilli ve Roubini (1995), Berument (2007), Çatık ve Martin (2012), Güloğlu ve İvrendi (2014) çalışmalarını desteklemektedir. Buna karşın sanayi üretim endeksinin tepkisi, hem yüksek hem düşük enflasyon döneminde önce negatif, daha sonra pozitif bir seyir izlemektedir. 
FED faiz oranlarındaki artış yönlü bir şok, yabancı paranın ülkeden çıkmasına ve bu nedenle döviz kurunun değer kazanmasına neden olmaktadır. Analizden elde edilen sonuçlar, döviz kurundaki artışın yurtiçi malları yabancı mallara göre ucuzlatarak ihracatı ve dolayısıyla üretim artışını uyarır yaklaşımı ile uyumludur. ECB faiz oranlarındaki artış, reel döviz kurunda azalışa ve fiyatlarda artışa neden olmaktadır. Faiz oranlarındaki bu artış karşısında, sanayi üretim endeksi pozitif ve negatif olmak üzere dalgalı bir tepki göstermektedir.

Para politikası araçlarının seçimi ve bunların ekonomik süreçlerdeki dalgalanmalara göre nasıl ve ne şekilde uygulanacağının belirlenebilmesinde, politika araçlarının hangi makroekonomik değişkenleri ne kadar zamanda ve ne yönde etkilediğinin bilinmesi ekonomi politikası yapımcıları ve uygulayıcıları açısından çok önemlidir. Özetle, çalışmadan elde edilen sonuçlar değerlendirildiğinde, FED para politikalarından kısa vadeli faiz politikasının Türkiye açısından ne denli önemli olduğunu bir kez daha göstermektedir.

\section{Kaynaklar}

Atış Gacener, A. (2014), “Merkez Bankacılığı ve Merkez Bankası-Banka İlişkileri”, iç. Banka İktisadı ve İşletmeciliği , Ed. N.O. Altay vd., Detay Yayıncılık, Ankara.

Atasanova, C. (2003), "Credit Market Imperfections and Business Cycle Dynamics: A Nonlinear Approach", Studies in Nonlinear Dynamics and Econometrics, 7(4), 1-22.

Balke, N. (2000), "Credit and Economic Activity: Credit Regimes and Non-linear Propagation of Shocks", Review of Economics and Statistics, 82, 344-349.

Bernanke, B.S. \& A.S. Blinder (2002), "The Federal Funds Rate and the Channels of Monetary Transmission", The American Economic Review, 82(4), 901-921.

Bernanke, B.S. \& I. Mihov (1998), "Measuring Monetary Policy", The Quarterly Journal of Economics, 113(3), 869-902.

Berument, H. (2007), "Measuring Monetary Policy for A Small Open Economy: Turkey”, Journal of Macroeconomics, 29(2), 411-430.

Bhuiyan, R. (2012), “The Effects of Monetary Policy Shocks in Bangladesh: A Bayesian Structural VAR Approach", International Economic Journal, 26(2), 301-316.

Borys, M.M. \& R. Horvath \& M. Franta (2009), "The effects of monetary policy in the Czech Republic: an Empirical Study", Empirica, 36, 419-443.

Cambazoğlu, B. \& H.S. Karaalp (2012), "The Effects of Monetary Policy Shock on Employment and Output: The Case of Turkey", Economics, Management, and Financial Markets, 7(4), 311-319.

Christiano, L. \& M. Eichenbaum \& C. Evans (1996), "The Effects of Monetary Policy Shocks: Evidnce from The Flow of Funds", Review of Economic and Statistics, 78, 16-34. 
Erer, E. \& D. Erer \& M. Çayır \& N.O. Altay (2016), “TCMB, FED ve ECB Para Politikalarının Türkiye Ekonomisi Üzerindeki Etkileri: 1994-2014 Dönemi Analizi”, Sosyoekonomi, Vol. 24(29), 285-305.

Chua, Y.S. (2012), "Assessing the Effects of Monetar Policy Shocks in Malaysia: A Factor Aughmented Vector Autoregressive Approach", The IUP Journal of Applied Economics, 11(3), 65-83.

Chuku A.C. (2009), "Measuring the Effects of Monetary Policy Innovations in Nigeria: A Structural Vector Autoregressive (SVAR) Approach", African Journal of Accounting, Economics, Finance and Banking Research, 5(5), 112-129.

Çatık, N. \& C. Martin (2012), "Macroeconomic Transitions and the Transmission Mechanism: Evidence from Turkey", Economic Modelling, 29, 1440-1449.

Doğan, B. (2012), “Geleneksel Aktarım Mekanizması: Türkiye Örneği”, Dumlupınar Üniversitesi Sosyal Bilimler Dergisi, 33, 211-220.

Ehrmann, M. \& L. Gambacorta \& J. Martinez-Pages \& P. Sevestre \& A. Worms (2003), "The Effects of Monetary Policy in the Euro Area", Oxford Review of Economic Policy, 19(1), $58-72$.

Galvao, B.A. \& M. Marcellino (2014), "The Effects of Monetary Policy Stance on the Transmission Mechanism”, Stud. Nonlinear Dyn. E., 18(3), 217-236.

Gorden, D.B. \& E.M. Leeper (1994), "The Dynamic Impacts of Monetary Policy: An Exercise in Tentative Identification”, Journal of Political Economy, 102, 228-247.

Grilli, V. \& N. Roubini (1995), "Liquidity and Exchange Rates: Puzzling Evidence from the G-7 Countries", Yale University Working Paper.

Güloğlu, B. \& M. İvrendi (2014), "The Effect of Monetary Stock on Exchange Rate under High Inflation: The Case of Turkey", Izmir Review of Social Sciences, 2(1), 17-40.

Halaç, U. (2015), "Parasal Aktarım Mekanizması", iç. Para Íktisadı-Teori ve Politika, Ed. N.O. Altay, Palme Yayıncilık, Ankara.

Jannsen, N. \& M. Klein (2011), "The International Transmission of Euro Area Monetary Policy Shocks", Kiel Working Paper No: 1718, 1-44; <https://www.ifw-members.ifwkiel.de/publications/the-international-transmission-of-euro-area-monetary-policyshocks/the-international-transmission-of-euro-area-monetary-policy-shocks.pdf>, 10.01.2015.

Kelilume, I. (2014), "Effects of the Monetary Policy Rate on Interest Rates in Nigeria", The International Journal of Business and Finance Research, 8(1), 45-55.

Kim, S. (2001a), "International Transmission of US Monetary Policy Shocks: Evidence from VARs", Journal of Monetary Economics, 48, 339-372.

Kim, S. (2001b), "Effects of Monetary Policy Shocks on the Trade Balance in Small Open European Countries", Economic Letters, 71, 197-203.

Kim, S. \& N. Roubini (2000), "Exchange Rate Anomalies in the Industrial Countries: A Solution with a Structural VAR Approach", Journal of Monetary Economics, 45, 561-586.

Lee, J. \& M.C. Strazicich (2003), "Minimum LM Unit Root Test with Two Structural Breaks", Review of Economis and Statistics, 85(4), 1082-1089.

Mishkin, F.S. (1995), "Symposium on the Monetary Transmission Mechanism", Journal of Economic Perspective, 9(4), 3-10. 
Mishkin, F.S. (2001), "The Transmission Mechanism And the Role of Asset Prices in Monetary Policy", NBER Working Paper Series, no: 8617;

<https://www0.gsb.columbia.edu/faculty/fmishkin/PDFpapers/w8617.pdf>, 05.01.2015.

Munir, K. \& A. Qayyum (2014), "Measuring the effects of monetary policy in Pakistan: a FactorAughmented Vector Autoregressive Approach", Empirical Economics, 46, 843-864.

Oktar, S. \& L. Dalyancı (2012), “Türkiye Ekonomisinde Para Politikasının Ekonomik Büyüme Üzerine Etkisi”, Marmara Üniversitesi I.I.I.B.F. Dergisi, 32(1), 1-18.

Örnek, İ. (2009), “Türkiye'de Parasal Aktarım Mekanizması Kanallarının İşleyişı”, Maliye Dergisi, 156, 104-125.

Peker, O. (2007), “Para Politikası Etkilerinin Ölçümü: Türkiye Örneği”, Yönetim ve Ekonomi Dergisi, 14(1), 181-194.

Sims, C.A. \& T. Zha (1998), "Does Monetary Policy Generate Recessions?", Federal Reserve Bank of Atlanta Working Paper No: 98/12, <http://sims.princeton.edu/yftp/mpolicy/szmd2.pdf>, 26.11.2014.

Sims, C.A. (1992), "Interpreting the Macroeconomic Time Series Facts: The Effects of Monetary Policy", European Economic Review, 36, 975-1000.

TCMB (2013), Parasal Aktarim Mekanizmasi, <http://www.tcmb.gov.tr/wps/wcm/connect/8cdd0f38-142f-493b-b489bdc0111491bb/ParasalAktarim.pdf?MOD=AJPERES >, 30.11.2014.

Tsay, R.S. (1998), "Testing and Modeling Multivariate Threshold Models", Journal of the American Statistical Association, 93(443), 1188-1202.

Vespignani, J.L. (2015), "International Transmission of Monetary Shocks to the Euro Area: Evidence from the U.S., Japan and China", Economic Modelling, 44, 131-141.

Ziaei, M.S. (2014), "Evaluating the Effects of Monetary Policy Shocks on Aggregate Demand Components in GCC Countries: Evidence from SVAR", The Journal of Developing Areas, 48(1), 405-423. 


\section{EKLER 1}

\section{TCMB-Doğrusal VAR}

Reel Efektif Döviz Kuru

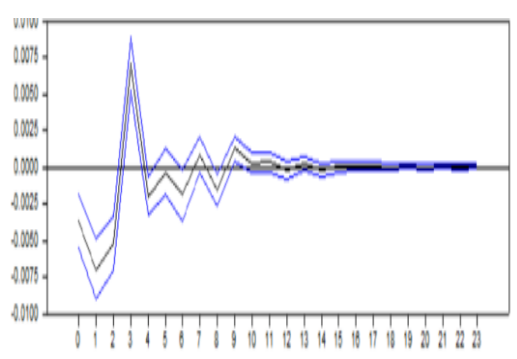

Efektif Döviz Kuru

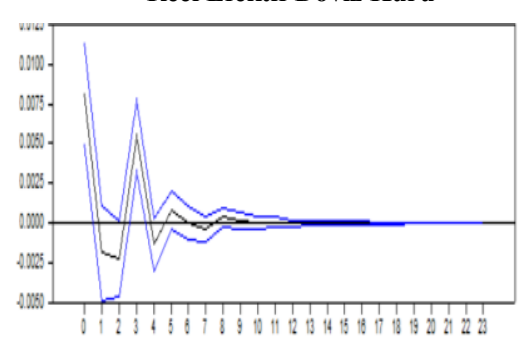

Tüketici Fiyat Endeksi

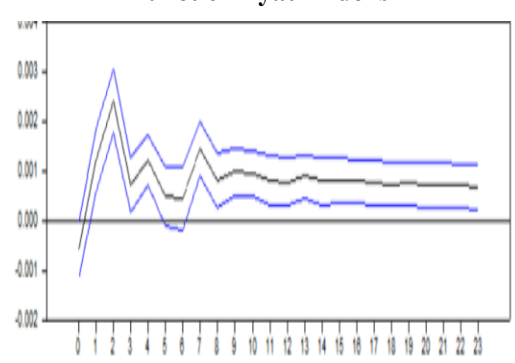

TCMB-Rejim 1

Tüketici Fiyat Endeksi

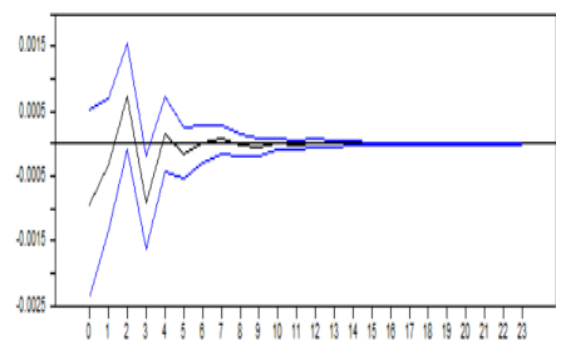

Sanayi Üretim Endeksi

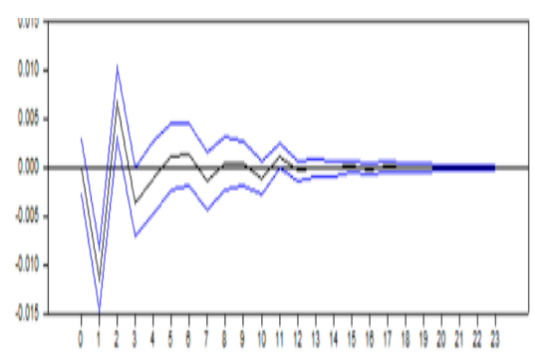

Sanayi Üretim Endeksi

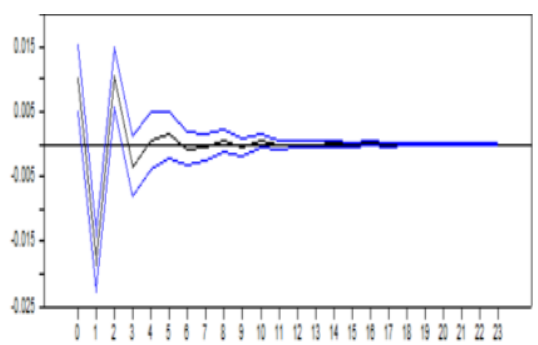


TCMB-Rejim 2

Reel Efektif Döviz Kuru

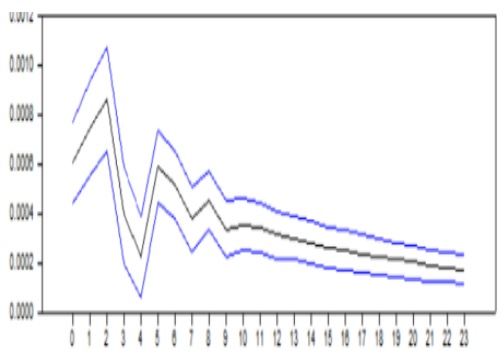

Reel Efektif Döviz Kuru

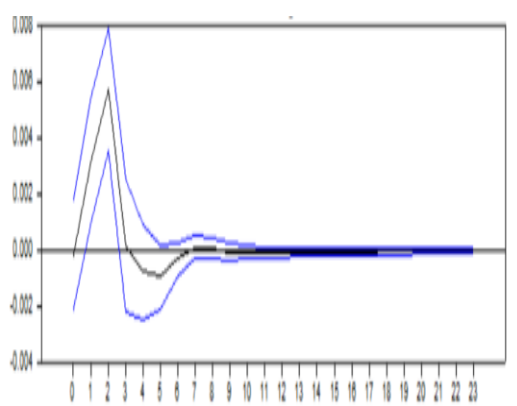

Tüketici Fiyat Endeksi

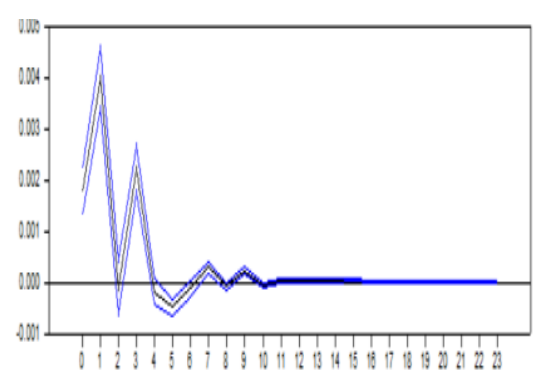

FED-DOĞRUSAL VAR

Tüketici Fiyat Endeksi

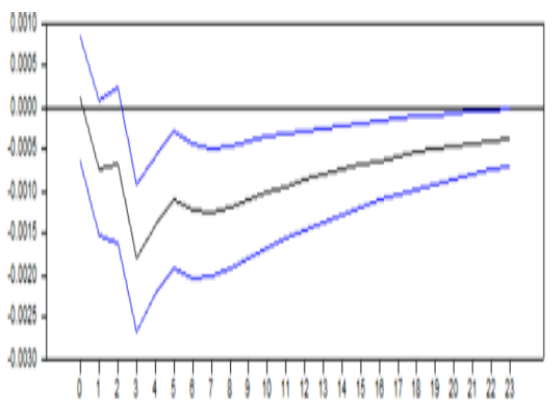

Sanayi Üretim Endeksi

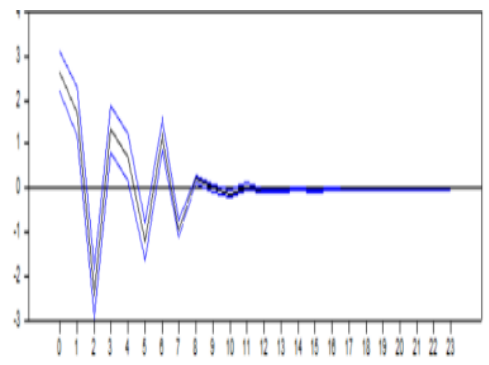

ayi Üretim Endeksi

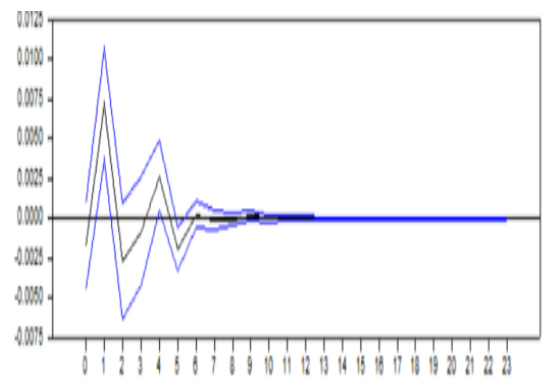


FED-REJIM 1

Reel Efektif Döviz Kuru

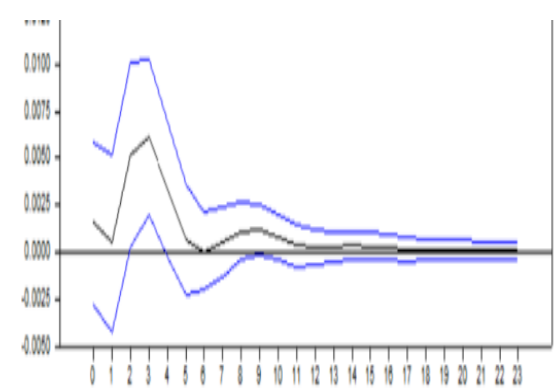

Efektif Döviz Kuru

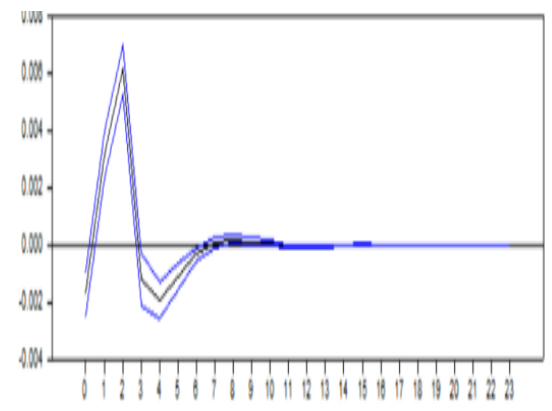

Tüketici Fiyat Endeksi

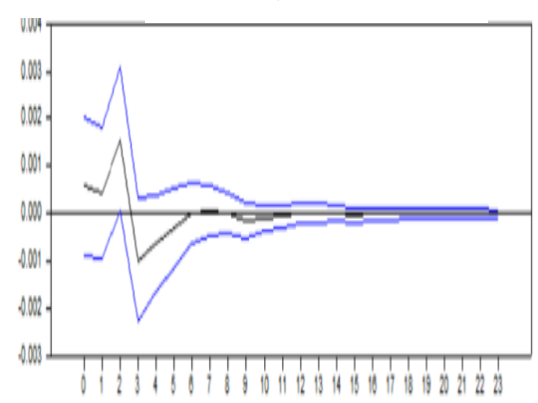

FED-REJIM 2

Tüketici Fiyat Endeksi

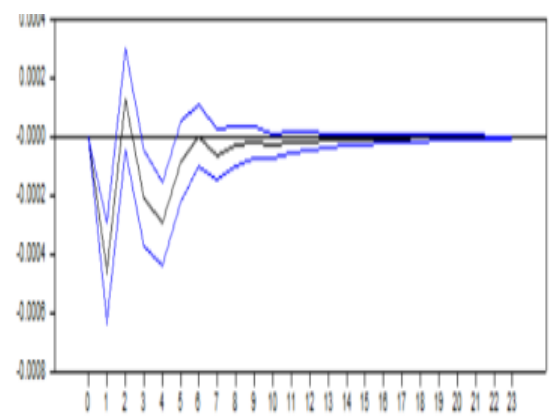

Sanayi Üretim Endeksi

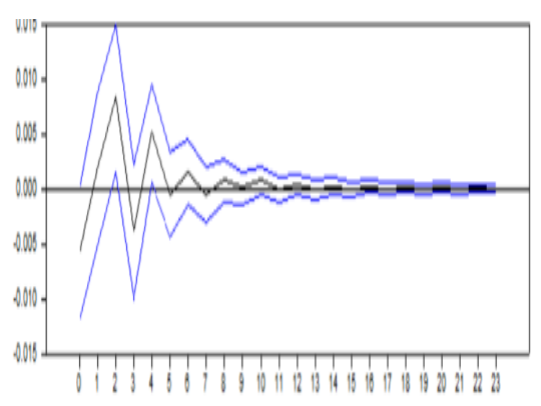

Sanayi Üretim Endeksi

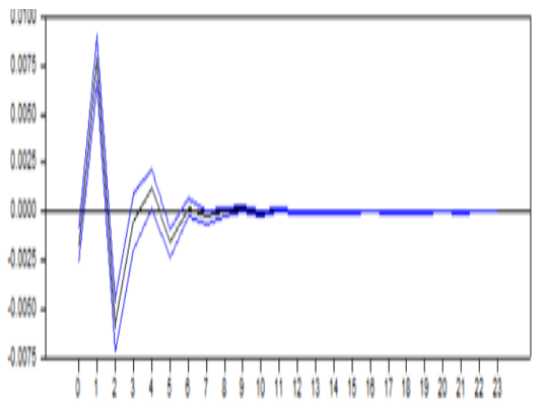




\section{ECB-DOĞRUSAL VAR}

Reel Efektif Döviz Kuru

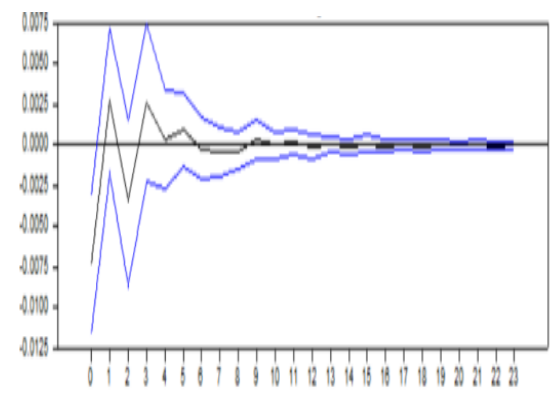

Reel Efektif Döviz Kuru

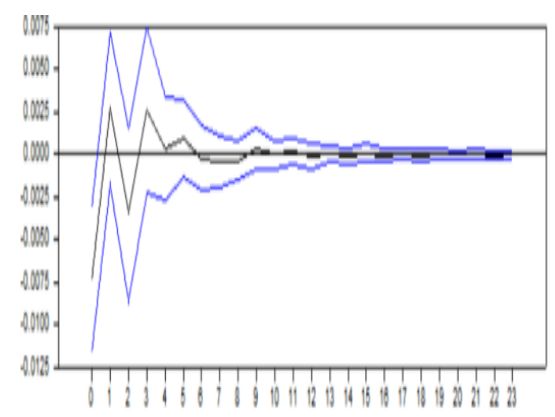

Tüketici Fiyat Endeksi

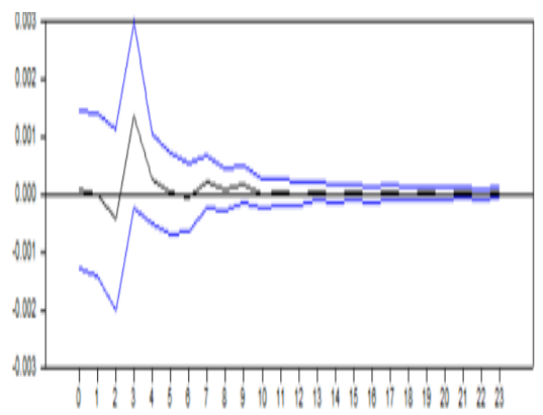

ECB-REJIM 1

Tüketici Fiyat Endeksi

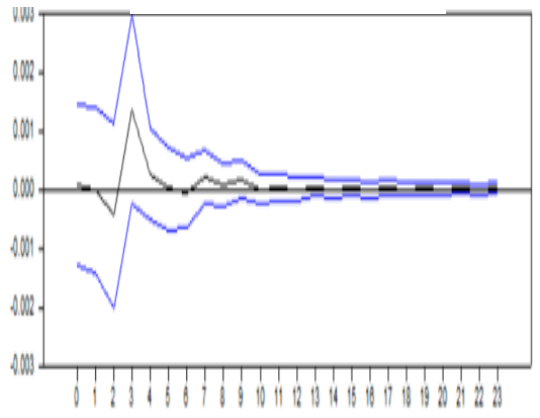

Sanayi Üretim Endeksi

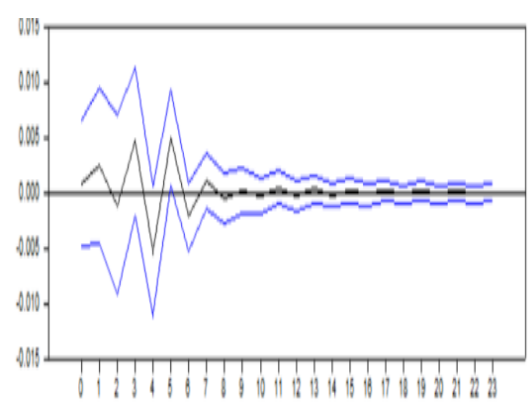

Sanayi Üretim Endeksi

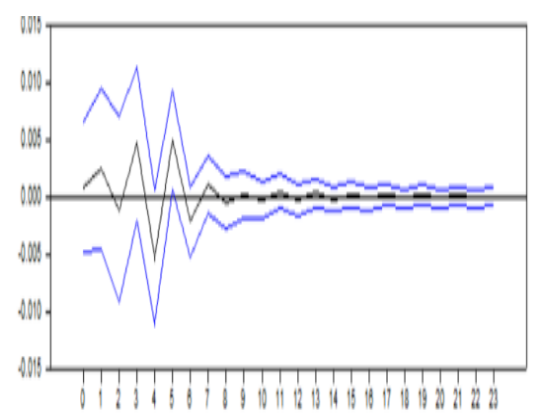




\section{ECB-REJIM 2}

Reel Efektif Döviz Kuru

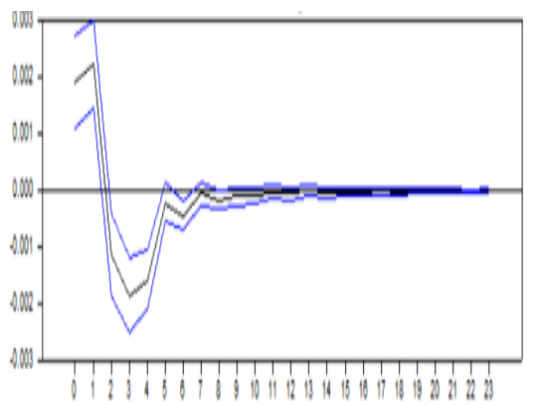

Tüketici Fiyat Endeksi

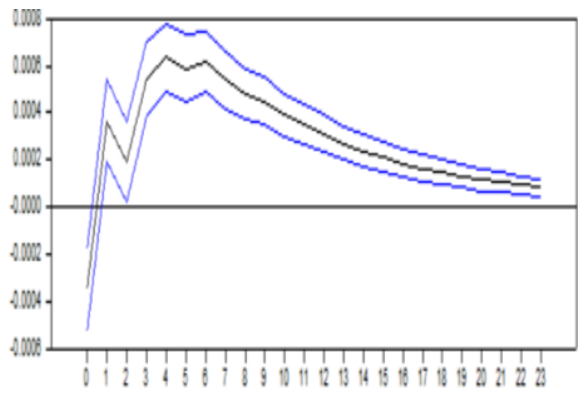

Sanayi Üretim Endeksi

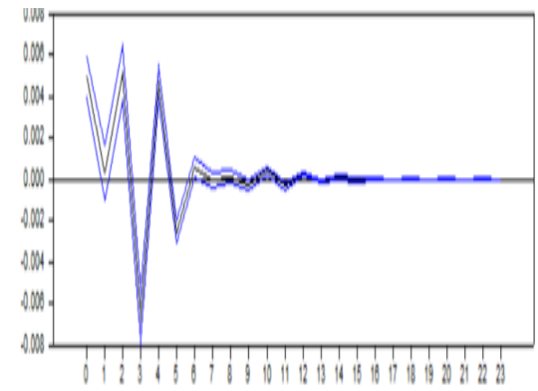

